\title{
Methodology for quantification of waste generated in Spanish railway construction works
}

\author{
Ana de Guzmán Báez ${ }^{a}$, Paola Villoria Sáez ${ }^{\mathrm{b}}$, Mercedes del Río Merino ${ }^{\mathrm{b}}$, Justo García Navarro ${ }^{\mathrm{a}, *}$

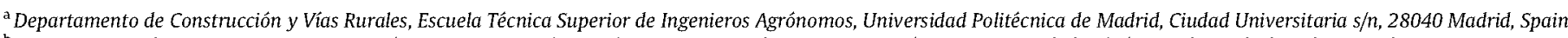 \\ ${ }^{\mathrm{b}}$ Departamento de Construcciones Arquitectónicas y su Control, Escuela Universitaria de Arquitectura Técnica, Universidad Politécnica de Madrid, Avda. Juan de Herrera 6 , \\ 28040 Madrid, Spain
}

Keywords:

Construction and demolition waste

Waste management

Quantification

Railway construction works

Construction stage

Waste categories

\begin{abstract}
A B S T R A C T
In the last years, the European Union (EU) has been focused on the reduction of construction and demolition (C\&D) waste. Specifically, in 2006, Spain generated roughly 47 million tons of C\&D waste, of which only $13.6 \%$ was recycled. This situation has lead to the drawing up of many regulations on C\&D waste during the past years forcing EU countries to include new measures for waste prevention and recycling. Among these measures, the mandatory obligation to quantify the $C \& D$ waste expected to be originated during a construction project is mandated. However, limited data is available on civil engineering projects.

Therefore, the aim of this research study is to improve C\&D waste management in railway projects, by developing a model for C\&D waste quantification. For this purpose, we develop two equations which estimate in advance the amount, both in weight and volume, of the C\&D waste likely to be generated in railway construction projects, including the category of C\&D waste generated for the entire project.
\end{abstract}

\section{Introduction}

The latest ratios found for construction and demolition (C\&D) waste generation and recycling in Spain are from 2006. This country generated roughly 47 million tons of $C \& D$ waste and only $13.6 \%$ of the C\&D waste generated was recycled (Eurostat, 2011). This ratio shows that the planning and carrying out of construction works have not considered environmental factors, as for the intensive construction activity from the last years, the low cost of dumping and the easy availability of natural resources has been the common trend. In addition, a study from the European Environment Agency (EEA) estimated that $65 \%$ on average of the waste was recycled in 2006 in the 27 European countries. Spain showed a quite lower figure for recycling than the EU average and was far from countries such as Denmark, Estonia and The Netherlands, with recycling indexes of over $90 \%$ (Tojo and Fischer, 2011).

The definition of C\&D waste both includes waste generated in building projects and civil engineering (Ministry of the Presidency, 2008). In this respect, Eurostat does not distinguish between C\&D waste generated in building projects and civil engineering works. However, the Spanish 2nd National Plan on C\&D waste shows a small distinction, claiming that civil works generated $28 \%$ from the total C\&D waste generated in 2006 (Ministry of the Environment, 2009).

\footnotetext{
* Corresponding author. Tel.: +349133658 63; fax: +34913363688.

E-mail address: justo.gnavarro@upm.es (J. García Navarro).
}

These data are still far from achieving the targets set by the EU to ensure that by $2020,70 \%$ in weight increase is achieved in the treatment, recycling and other valorization operations of nonhazardous C\&D waste, excluding the ones in the 170504 category of the European Waste Catalogue (EWC) (Ministry of the Environment, 2002).

Aware of this situation, the EU countries are implementing national policies as well as different measures to increase recycling and recovering. In particular, the Spanish Government issued the 105/2008 Royal Decree (RD) (Ministry of the Presidency, 2008). This RD regulates the production and management of $C \& D$ waste and focuses on establishing a legal frame for the C\&D waste production so as to encourage prevention, reuse and recycling, as well as other forms of valorization.

Within this RD, the obligation to develop a waste management plan for each construction project is of special interest. It should necessarily include an estimated approach of the amount of the C\&D waste suitable to be generated. However, no tools or models are available to help construction agents in estimating in advance the C\&D waste to be generated in civil engineering works, needed in the regulations. This unsustainable situation has not only worried EU countries, but it has been of great interest for researchers in the field, drawing special attention to the $C \& D$ waste management (Yuan and Shen, 2011).

During the last years, research within the civil engineering sector has focused on the use of the C\&D waste as new construction materials for bases, sub-bases and firms. Among these studies, 
Poon and Chan (2006), Aatheesan et al. (2008), Courard et al (2010), and Kuo et al. (2010) can be highlighted. In addition, other specific works using C\&D waste in railway projects include research works by Helsen et al. (1998), Indraratna and Salim (2003) and Krezel et al. (2004). However, another pending research line to be emphasized in civil engineering is the way to optimize management including quantifying methods of C\&D waste generation, as has already been developed in the building sector (Bossink and Brouwers, 1996 and Llatas, 2011).

Previous studies quantifying C\&D waste generation in building construction works can be classified in two groups: ones which quantify C\&D waste in relation to the built area and others estimating the annual generation of $C \& D$ waste in relation to a region. Among the researchers in the first group, Mañà I Reixach et al. (2000) obtained the C\&D waste generated per surface area for different constructive systems, considering the construction stages. Furthermore, the study carried out by Chadrakanthi et al. (2002) in Canada uses simulation models to establish the generation of waste in construction projects based on the schedule of construction activities. Specifically for the situation in Spain, Solís-Guzmán et al. (2009) and Villoria Sáez et al. (2011) studied models for C\&D waste quantification and management based on budget data of building works. Among studies using annual data, such as the construction licenses, Hsiao et al. (2002), Conchran et al. (2007) and Kofoworola and Gheewala (2009) can be pointed out. Regarding the second group - estimating annual generation of C\&D waste by region - the studies performed are: Yost and Halstead (1996), Fatta et al. (2003), Müller (2006) and Martínez Lage et al. (2010).

In short, research on $C \& D$ waste quantification states that waste generation rates serve as valuable benchmark quantitative information for different $C \& D$ waste management practices in the building sector (Yuan and Shen, 2011). In this regard, from the literature review analyzed, further studies should be launched to determine waste generation rates in the civil engineering sector.

Therefore, this study aims to define two equations to quantify in advance the $C \& D$ waste expected to be generated in railway construction projects. Moreover, C\&D waste percentages are obtained regarding the categories defined in the EWC and the amount of the $C \& D$ waste produced in each construction stage. This information will be necessary to fulfil the $C \& D$ waste estimation in the Management Plan.

\section{Materials and methods}

The estimation of the $C \& D$ waste generated in railway projects needs to be assessed regarding the characteristics of the project. In order to do so, the methodology followed in this study unfolds in four different phases:

- Selection of works.

- Structure of the bill of quantities.

- Data collection of the waste generated in the selected works.

- Procedure for the calculation of the amount of C\&D waste generated in railway works.

\subsection{Selection of works}

This research focuses on railway projects in Spain. In general, these infrastructures present a series of common characteristics (functional units), from which a number of them are distinguished:

- Kilometres of railway $\left(\mathrm{L}_{\mathrm{r}}\right)$.

- Number of intersections, junctions $\left(\mathrm{N}_{\mathrm{j}}\right)$.

- Number of transversal drainage $\left(\mathrm{N}_{\mathrm{td}}\right)$.

- Number of underpasses $\left(\mathrm{N}_{\mathrm{u}}\right)$.
- Number of overpasses $\left(\mathrm{N}_{\mathrm{o}}\right)$.

- Kilometres of viaduct $\left(\mathrm{L}_{\mathrm{v}}\right)$.

- Kilometres of tunnel $\left(\mathrm{L}_{\mathrm{t}}\right)$.

For this study, railway projects carried out by Fomento Construcciones y Contratas (FCC) Company have been used. A total of $14.60 \mathrm{~km}$ of railway road have been analyzed with up to $4 \mathrm{~km}$ of intersections and junctions, 11 units of transversal drainage, 10 underpasses, 1 overpass, a viaduct of $0.59 \mathrm{~km}$ and a tunnel of $9.53 \mathrm{~km}$.

\subsection{Structure of the bill of quantities}

This study collects data from the reports and bill of quantities of the selected work projects. Due to the lack of homogeneity in the structure of the construction stages in the bill of quantities, the following guidelines were established to facilitate the comparison of the results:

- Bills of quantities had to have a similar construction stage structure in the different projects, where the elements of work were clearly identified.

- A standardized classification of the bill of quantities should be provided so that it can be extrapolated to other projects of similar characteristics.

- The construction work stages should contain similar elements of work.

Regarding these guidelines, bills of quantities are divided into the following stages and substages of work:

- Preliminary and explanation works

- Drainage:

- Longitudinal drainage; Transversal drainage (TD)

- Structures:

- Underpasses; Overpasses; Viaducts

- Junction

- Linking paths

- Tunnel

- Temporary detours

\subsection{Data collection of the waste generated in the selected works}

To quantify the weight and volume of C\&D waste generated, the online available BEDEC database from the Technological Institute of Catalonia (ITeC) has been used (BEDEC, 2011). This database gives environmental parameters for each element of work in the bill of quantities of the projects. In this sense, values of the following environmental parameters for the analyzed railway works have been obtained from BEDEC: volume $\left(\mathrm{m}^{3}\right)$ and weight $(\mathrm{kg})$ for each waste category (EWC code). Both environmental parameters have been identified not only for each of the substages from the analyzed projects, but also for each stage and for the whole railway construction.

In this study, soil and rocks not containing hazardous substances have been excluded (EWC code: 1705 04) because the 2008/98/EC Directive of 19 November on waste does not consider them as such (European Parliament, 2008). An example of how the data is obtained can be seen in Table 1 which shows, a fragment from one of the analyzed substages for the quantification of C\&D waste generated in a viaduct construction.

\subsection{Procedure for the calculation of the amount of $C \& D$ waste generated in railway works}

A method is determined to calculate C\&D waste volume and weight generated in railway projects, through two empirical 
Table 1

Example of $C \& D$ waste quantification generated in the viaduct substage (Structures stage) in volume.

\begin{tabular}{|c|c|c|c|c|c|}
\hline \multirow[t]{3}{*}{ Unit } & \multirow{2}{*}{\multicolumn{2}{|c|}{ Element of work }} & \multicolumn{3}{|c|}{ Environmental parameters } \\
\hline & & & \multicolumn{2}{|c|}{ Waste per Unit ${ }^{\mathrm{a}}$} & \multirow[t]{2}{*}{$\mathrm{T}_{\mathrm{e}}^{\mathrm{b}}\left(\mathrm{m}^{3}\right)$} \\
\hline & Description & Quantity (Unit) & EWC Code & Volume $\left(\mathrm{m}^{3}\right)$ & \\
\hline$m^{3}$ & Mass concrete for packings, levelling layers and cleaning. & 79.732 & 170101 & $1.00 \times 10^{-02}$ & 0.80 \\
\hline$m^{3}$ & Reinforced concrete in foundations, piles, screens, etc. & 1990.690 & 170101 & $1.00 \times 10^{-02}$ & 19.91 \\
\hline $\mathrm{kg}$ & Reinforcement steel bars. & $431,329.601$ & 170405 & $8.03 \times 10^{-06}$ & 3.46 \\
\hline \multicolumn{3}{|c|}{ Total waste of the substage } & & & $\sum \mathrm{T}_{\mathrm{e}}$ \\
\hline
\end{tabular}

a Data obtained from BEDEC.

b Total C\&D waste for each element work.

equations. Eqs. (1) and (2) relate these quantities - volume and weight - to the functional units (railway length, number of junctions, length of viaducts, etc.) of the railway project to be analyzed.

$\mathrm{Q}_{\mathrm{p}}=a_{\mathrm{p}} \cdot \mathrm{L}_{\mathrm{r}}+b_{p} \cdot \mathrm{N}_{\mathrm{j}}+c_{p} \cdot \mathrm{N}_{\mathrm{td}}+d_{p} \cdot \mathrm{N}_{\mathrm{u}}+e_{p} \cdot \mathrm{N}_{\mathrm{o}}+f_{p} \cdot \mathrm{L}_{\mathrm{v}}+g_{p} \cdot \mathrm{L}_{\mathrm{t}}$

$\mathrm{Q}_{\mathrm{v}}=a_{\mathrm{v}} \cdot \mathrm{L}_{\mathbf{r}}+b_{v} \cdot \mathrm{N}_{\mathrm{j}}+c_{v} \cdot \mathrm{N}_{\mathrm{td}}+d_{v} \cdot \mathrm{N}_{\mathrm{u}}+e_{v} \cdot \mathrm{N}_{\mathrm{o}}+f_{v} \cdot \mathrm{L}_{\mathrm{v}}+g_{v} \cdot \mathrm{L}_{\mathrm{t}}$

where $Q_{p}$ is $C \& D$ waste weight $(\mathrm{kg}), \mathrm{Q}_{\mathrm{v}}$ is $C \& D$ waste volume $\left(\mathrm{m}^{3}\right)$, $n_{p}$ is a constant value for weight calculation (kg/unit) and $n_{\nu}$ is a constant value for volume calculation ( $\mathrm{m}^{3} / \mathrm{unit}$ ).

In Eqs. (1) and (2) the functional units are determined by the railway project characteristics. In addition, Eq. (3) has been used to obtain the constants $\left(n_{p}\right.$ or $\left.n_{v}\right)$.

$n=\mathrm{Q} / \mathrm{Q}_{\mathrm{fu}}$

where $n$ is the constant value, $Q$ is the total $C \& D$ waste and $Q_{f u}$ is the quantity of functional unit.

At the same time, the percentages for each C\&D waste category and for each construction stage, from the total C\&D waste generated, have also been obtained.

\section{Results and discussion}

\subsection{Analysis of the total CED waste generated}

From the relation between the amount of C\&D waste obtained in the analysis of the studied projects and their functional units (Eq. (3)), seven empirical constants have been obtained (Table 2).

These constant values achieved can be used to estimate in advance the $C \& D$ waste generated in similar railway projects, by introducing them in Eqs. (1) and (2) along with the particular functional units of the railway project to be studied.While the constant values determined are derived from Spanish railway constructions works, this methodology can be applied to other similar areas or infrastructures in different scenarios.

\subsection{Analysis according to CED waste category}

The generated waste in the railway projects analyzed, according to the EWC code, is identified as follows:

- 150101 Paper and cardboard packaging

- 150102 Plastic packaging

- 150103 Wooden packaging

- $150110^{*}$ Packaging containing residues of or contaminated by dangerous substances

- 170101 Concrete

- 170103 Tiles and ceramics

- 170201 Wood

- 170203 Plastic

- 170302 Asphalt not containing tar 170405 Iron and steel

- 170407 Mixed metals

- 170904 Mixed construction and demolition waste or separated fractions not containing dangerous substances.

Once the total quantities, both in weight and in volume, have been obtained for each category (see example in Table 1), results show that the mixed $C \& D$ waste not containing hazardous substances (EWC code: 170904 ) are the most generated ones in railway construction works (Fig. 1). They represent 55\% in weight and $85 \%$ in volume of the total C\&D waste generated.

Mixed C\&D waste not containing hazardous substances are the most generated mainly due to the lack of C\&D waste segregation onsite, despite the usual space available in railway construction works to do so. This waste category is followed by the bituminous mixtures (EWC code: 170302 ) that in turn, represent 7\% in volume and $25 \%$ in weight. On the other hand, plastic (EWC code: 150102 ), wood packaging wastes (EWC code: 150103 ) and empty hazardous waste containers (EWC code: 1501 10*) are

Table 2

Empirical constants calculation.

\begin{tabular}{|c|c|c|c|c|c|c|c|c|}
\hline \multicolumn{2}{|c|}{ Functional unit } & \multirow[t]{2}{*}{$\mathrm{Q}_{f u}{ }^{a}$} & \multirow[t]{2}{*}{$\mathrm{Q}_{\mathrm{p}}^{\mathrm{b}}$} & \multirow[t]{2}{*}{$\mathrm{Q}^{\mathrm{c}}$} & \multicolumn{2}{|c|}{ Weight (kg/unit) } & \multicolumn{2}{|c|}{ Volume ( $\mathrm{m}^{3} /$ unit) } \\
\hline & & & & & \multicolumn{2}{|l|}{$n_{p}$} & \multicolumn{2}{|l|}{$\mathrm{n}_{\mathrm{v}}$} \\
\hline $\mathrm{L}_{\mathrm{r}}$ & $(\mathrm{km})$ & 14.60 & $3.24 \times 10^{7}$ & $7.39 \times 10^{4}$ & $a_{p}$ & $2.22 \times 10^{6}$ & $a_{v}$ & $5.06 \times 10^{3}$ \\
\hline $\mathrm{N}_{j}$ & (unit) & 4 & $1.13 \times 10^{6}$ & 10.1 & $b_{p}$ & $2.82 \times 10^{5}$ & $b_{v}$ & 2.53 \\
\hline $\mathrm{N}_{t d}$ & (unit) & 11 & $1.15 \times 10^{5}$ & 47.1 & $c_{p}^{p}$ & $1.05 \times 10^{4}$ & $c_{v}$ & 4.28 \\
\hline $\mathrm{N}_{u}$ & (unit) & 10 & $4.16 \times 10^{5}$ & $1.94 \times 10^{2}$ & $d_{p}$ & $4.16 \times 10^{4}$ & $d_{v}$ & 19.4 \\
\hline $\mathrm{N}_{o}$ & (unit) & 1 & $1.21 \times 10^{4}$ & 4.83 & $e_{p}$ & $1.21 \times 10^{4}$ & $e_{v}$ & 4.83 \\
\hline $\mathrm{L}_{v}$ & $(\mathrm{~km})$ & 0.59 & $5.23 \times 10^{5}$ & $2.53 \times 10^{2}$ & $f_{p}^{p}$ & $8.87 \times 10^{5}$ & $f_{v}$ & $4.29 \times 10^{2}$ \\
\hline $\mathrm{L}_{t}$ & $(\mathrm{~km})$ & 9.528 & $1.71 \times 10^{7}$ & $5.49 \times 10^{4}$ & $g_{p}$ & $1.80 \times 10^{6}$ & $g_{v}$ & $5.76 \times 10^{3}$ \\
\hline
\end{tabular}

a Quantities of the functional units.

b Total weight of C\&D waste $(\mathrm{kg})$

c Total volume of C\&D waste $\left(\mathrm{m}^{3}\right)$. 


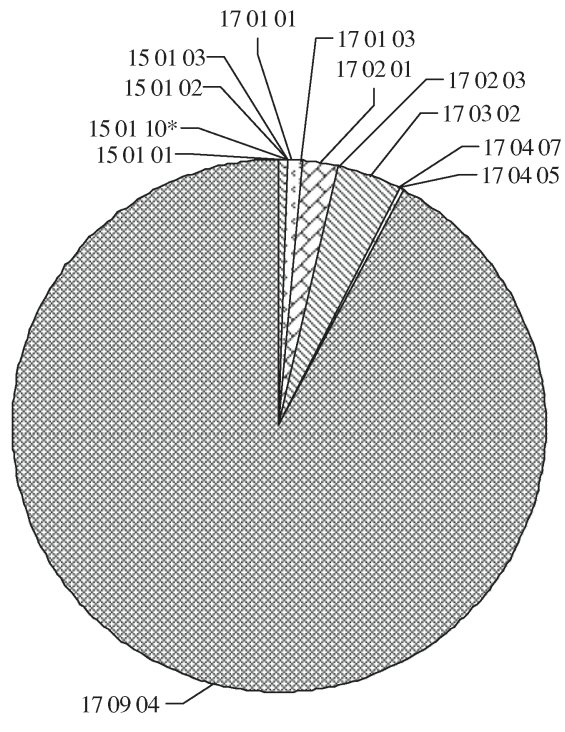

A

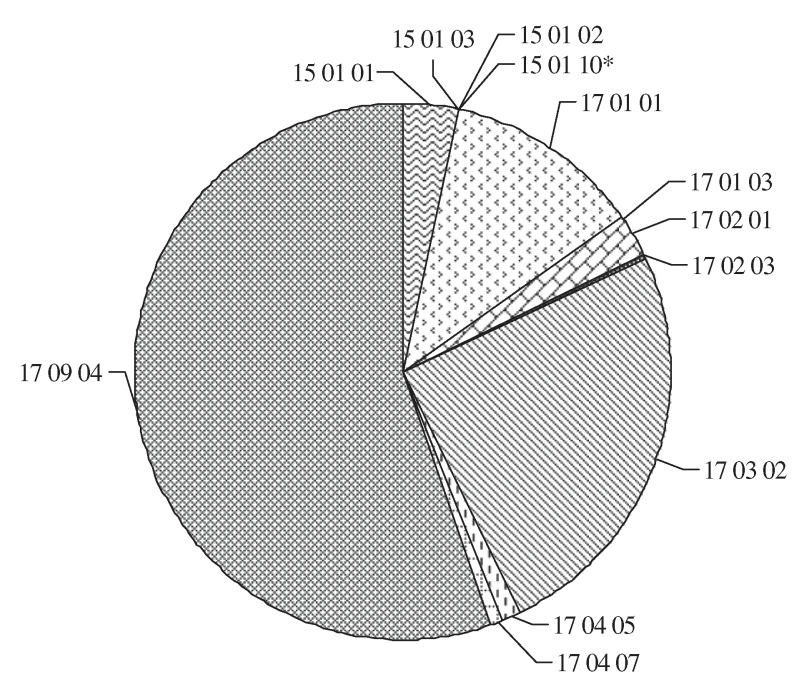

B

Fig. 1. Percentage of $C \& D$ waste generated in $(A)$ volume $\left(\mathrm{m}^{3}\right)$ and $(B)$ weight $(\mathrm{kg})$ for railway projects as categorized by the EWC.

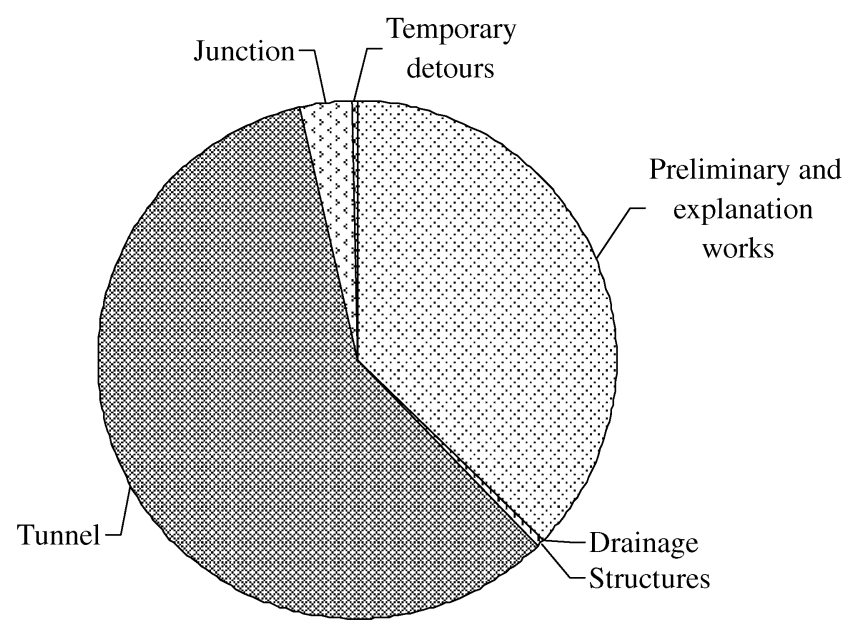

A

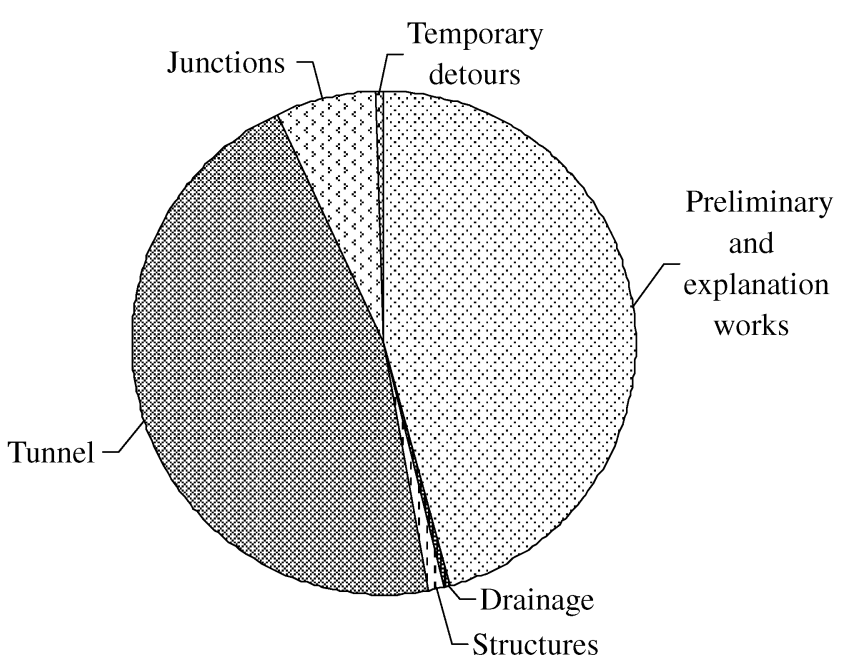

B

Fig. 2. Percentage of $C \& D$ waste generated in $(A)$ volume $\left(\mathrm{m}^{3}\right)$ and $(B)$ weight $(\mathrm{kg})$ for railway projects according to the construction stages.

generated in smaller proportions, not even reaching $0.1 \%$ in weight and volume.

Furthermore, waste categories such as mixed C\&D waste (EWC code: 1709 04) or wood (EWC code: 1702 01), occupy huge volumes in the construction site in relation to their weight. In this sense, the use of mobile waste treatment plants for grinding and crushing or other measures could be considered.

\subsection{Analysis according to the construction stage}

Besides knowing the most generated $C \& D$ waste category regarding the EWC code, considering the construction stage in which the waste is generated, is also important. Therefore, the data obtained has been also analysed regarding the construction stages.

Fig. 2 shows that the largest amount of C\&D waste is generated during the tunnel construction, accounting for $59 \%$ of the total waste generated in volume and $46 \%$ in weight. This construction stage is followed by the preliminary and explanation works, which represent $37 \%$ in volume of the total C\&D waste generated, and $46 \%$ in weight. These two construction stages are to be deeply analyzed by engineers during the design phase of a railway construction work in order to plan the appropriate management for each waste category to be generated. On the other hand, the construction stages that generate less $C \& D$ waste correspond to drainage and temporary detours, not exceeding $7 \%$ both in weight and in volume.

\section{Conclusions}

From the analysis performed in this study the following conclusions can be drawn: 
- The quantification tools for C\&D waste generation presently being used in civil projects are not detailed enough to answer to the increasing social pressure in relation to environmental concerns.

- A relationship between the amount of $C \& D$ waste generated and the functional units of the railway has been proved and stated in the two equations proposed in this study (Eqs. (1) and (2)).

- The most generated C\&D waste category in railway works corresponds to mixed C\&D waste (EWC code: 1709 04). In general, packaging wastes and empty hazardous waste containers are the less significant waste generated.

- The construction of a tunnel in a railway becomes essential to quantify in advance the waste suitable to be generated during the works. Moreover, if construction agents focus their efforts in the waste generated in tunnels and preliminary and explanation works, more than $90 \%$ of the total waste generated in railway works could be properly managed.

- The C\&D waste percentages obtained imply a thorough knowledge of the kind of waste, the quantity and even the stage within the construction process in which it will be generated.

- The methodology provided can be applied to obtain new equations for other particular areas, with new constant values representing their specific characteristics.

In short, the methodology presented can help in assigning an optimal and systematic management of the C\&D waste produced and assist the construction agents in developing the waste management plans according to the existing legislation.

\section{Acknowledgements}

The authors would like to thank Fomento Construcciones y Contratas (FCC) Company, especially the Department of Environment, for supplying the information about railway projects performed by the company that was basic for this study. This research study has been concluded in the Framework of the CLEAM Project, partially funded by The Centre for the Development of Industrial Technology (CDTI) within the CENIT program. Its results are, consequently, exclusive property of the companies that carry out the Project and constitute the CLEAM CENIT, AIE.

\section{References}

Aatheesan, T., Arulrajah, A., Wilson, J.L., 2008. Beneficial use of brick rubble as pavement sub-base material. In: Proceedings of the 1st International Conference on Transportation Geotechnics. Nottingham, England, pp. 695-699. ISBN: 978-0-415-47590-7.

BEDEC, 2011. Instituto de Tecnología de la Construcción de Cataluña (ITeC), Spain. Available from: <http:/www.itec.es/nouBedec.e> Last accessed: 18/12/2011.

Bossink, B.A.G., Brouwers, H.J.H., 1996. Construction waste: quantification and source evaluation. Journal of Construction Engineering and Management 122, 55-60.

Chadrakanthi, M., Hettiarachi, P., Prado, B., Ruwanpura, J., 2002. Optimization of waste management for construction projects using simulation. In: Proceedings of the 34th Winter Simulation Conference: Exploring New Frontiers, San Diego, California, USA, pp. 1771-1777. ISBN 0-7803-7615-3.

Cochran, K.M., Townsend, T.G., Reinhart, D., Heck, H., 2007. Estimation of regional building-related C\&D debris generation and composition: Case study for Florida, US. Waste Management 27, 921-931.
Courard, L., Michel, F., Delhez, P., 2010. Use of concrete road recycled aggregates for roller compacted concrete. Construction and Building Materials 24, 390-395.

European Parliament, 2008. Directive 2008/98/CE of the European Parliament and of the council of 19 November 2008 on waste and repealing certain Directives. Official Journal of the European Union $\mathrm{L} 312,0003-0030$.

Eurostat, 2011. European Communities. Statistics on focus. Available from: $<$ http:// epp.eurostat.ec.europa.eu/tgm/

refreshTableAction.do?tab=table\&plugin $=1$ \&pcode=ten00106\&language=en > Last accessed: $18 / 12 / 2011$.

Fatta, D., Papadopoulus, A., Sgourou, E., Moustakas, K., Kourmoussis, F., Mentzis, A., Loizidou, M., 2003. Generation and management of construction and demolition waste in Greece - an existing challenge. Resources, Conservation and Recycling 40, 81-91.

Helsen, L., Van den Bulck, E., Hery, J.S., 1998. Total recycling of CCA treated wood waste by low-temperature pyrolysis. Waste Management 18, 571-578.

Hsiao, T.Y., Huang, Y.T., Yu, Y.H., Wernick, I.K., 2002. Modeling materials flow of waste concrete from construction and demolition wastes in Taiwan. Resources Policy 28, 39-47.

Indraratna, B., Salim, W., 2003. Deformation and degradation mechanics of recycled ballast stabilised with geosynthetics. Soils and Foundations 43, 35-46.

Kofoworola, O.F., Gheewala, S.H., 2009. Estimation of construction waste generation and management in Thailand. Waste Management 29, 731-738.

Kuo, M.F., Du, J.C., Shen, D.H., 2010. Crushed waste concrete in stone mastic asphalt mixtures. Baltic Journal of Road and Bridge Engineering 5, 164-168.

Krezel, Z.A., McManus, K.J., Harding, G.E., 2004. The use of layered recycled aggregate concrete barriers in targeting urban noise. In: Proceedings of 3rd International Conference on Urban Regeneration and Sustainability. Sustainable City III: Urban Regeneration and Sustainability. Siena, Italy. ISBN: 1-85312720-5.

Llatas, C., 2011. A model for quantifying construction waste in projects according to the European waste list. Waste Management 31, 1261-1276.

Mañà i Reixach, F., Gonzàlez i Barroso, J., Sagrera i Cuscó, A., 2000. Plan de gestión de residuos en las obras de construcción y demolición (Waste management plan in the construction and demolition works). First ed. Barcelona, Spain. ISBN: 847853-393-1.

Martínez Lage, I., Martínez Abella, F., Vázquez Herrero, C., Pérez Ordóñez, J.L., 2010. Estimation of the annual production and composition of C\&D Debris in Galicia (Spain). Waste Management 30, 636-645.

Müller, D.B., 2006. Stock dynamics for forecasting material flows - Case study for housing in the Netherlands. Ecological Economics 59, 142-156.

Ministry of the Presidency, 2008, 2008. Real Decreto 105/2008, de 1 de Febrero, por el que se Regula la Producción y Gestión de los Residuos de Construcción y Demolición (Royal Decree 105/2008, February 1, which Regulates the Production and Management of Construction and Demolition Waste). Ministry of the Presidency, Madrid, Spain. Official journal of the Spanish government (BOE) $38,7724-7730$.

Ministry of the Environment, 2002, 2002. Orden MAM/304/2002, de 8 de febrero por la que se publican las operaciones de valorización y eliminación de residuos y la lista europea de residuos. Ministry of the Environment, Madrid, Spain. Official journal of the Spanish government (BOE) 43, 6494-6515.

Ministry of the Environment, 2009, 2009. II Plan Nacional de Residuos de Construcción y Demolición 2008-2015 (2nd National C\&D Waste Plan 20082015). Ministry of the Environment, Madrid, Spain. Official journal of the Spanish government (BOE) 49, 19938-19948.

Poon, C.S., Chan, D., 2006. Feasible use of recycled concrete aggregates and crushed clay brick as unbound road sub-base. Construction and Building Materials 20 , 578-585.

Solís-Guzmán, J., Marrero, M., Montes-Delgado, M.V., Ramírez-de-Arellano, A., 2009. A Spanish model for quantification and management of construction waste. Waste Management 29, 2542-2548.

Tojo, N., Fischer, C., 2011. Europe as a Recycling Society: European recycling policies in relation to the actual recycling achieved. European Environment Agency. European Topic Centre on Sustainable Consumption and Production, Copenhague, Denmark.

Villoria Sáez, P., del Río Merino, M., Porras-Amores, C., 2011. Estimation of construction and demolition waste volume generation in new residential buildings in Spain. Waste Management \& Research, doi:20110734242X114 23955.

Yost, P., Halstead, J., 1996. A methodology for quantifying the volume of construction waste. Waste Management \& Research 14, 453-461.

Yuan, H., Shen, L., 2011. Trend of the research on construction and demolition waste management. Waste management $31,670-679$. 